\title{
Digital Entrepreneurship and Education: Support for Innovative Projects
}

\author{
Elena Nikolaevna Muraya ${ }^{1}$, Vladimir Robertovich Roganov ${ }^{2}$, Elena Ivanovna Skiteva ${ }^{3}$, Irina Vladimirovna \\ Evgrafova $^{4}$, Ismail Lemievich Daudov ${ }^{5}$ \\ ${ }^{1}$ Far Eastern State Transport University, Khabarovsk, Russia \\ ${ }^{2}$ Penza State Technological University, Penza, Russia \\ ${ }^{3}$ Emperor Alexander I St. Petersburg State Transport University, St. Petersburg, Russia \\ ${ }^{4}$ State Marine Technical University of St.Petersburg, St. Petersburg, Russia \\ ${ }^{5}$ Chechen State University, Grozny, Russia
}

\begin{abstract}
In the modern conditions of globalization, an important factor in the modification of business models of business structures is the Internet and the resulting rapid development of digital entrepreneurship. In the shortest period, digital entrepreneurship has changed the nature of many markets, given entrepreneurs new driving forces, and provided key factors for success in the competitive struggle.

The article aims to substantiate the theoretical and practical foundations of the development of the educational component of digital entrepreneurship.
\end{abstract}

The article defines the essence of digitization of the economy at the theoretical level, presents the characteristics of the digital economy, describes the concepts of digitization and digital entrepreneurship, and identifies the current trends of entrepreneurship digitization.

Based on an expert survey, the authors have identified key factors for effective development of business models, digital entrepreneurship, and characteristics of the architectural component of this area, as well as developed methodological recommendations for the study objectives and content of the distance learning course corresponding to the thematic focus.

Key words : business models, digital economy, digital entrepreneurship, digitization, distance learning.

\section{INTRODUCTION}

At present, the growth of the Russian economy is largely determined by the level of innovative development of subjects of market relations, based on their efforts to use the latest technologies in their economic activities, as well as the ability to creatively determine ways to meet the needs of consumers and improve and update products, strengthening the market position and ensuring the efficiency of business [1], [2]. That is, the feature of the activities of modern entrepreneurs is that innovation has become an endogenous factor of the effectiveness of their development [3], [4].

The problems of development of digital entrepreneurship in Russia are connected with the need to apply the latest electronic technologies and services, informatization of production processes in business, and improvement of digital skills and competencies of the population [5], [6]. Technologies of electronic identification and electronic banking fill modern economic life with a new meaning, which is based on new knowledge and trained specialists [7], [8]. The application of e-business methods and models is becoming one of the main market advantages for many companies. In this regard, the study of theoretical and methodological approaches to determining the main trends in the development of digital entrepreneurship is relevant.

The transition to the digital economy forces one to revise the entire current economic system of Russia, starting from its architecture and mechanisms for ensuring the functioning and ending with individual tools for doing business and training [9], [10]. At the same time, the meaning and purpose of the educational process and training of specialists have changed. They moved from the plane of knowledge, skills, and abilities of the individual to the mastery of professional competencies developed according to established standards. In this regard, first of all, issues of support for innovative projects and educational programs in the field of digital entrepreneurship are of particular importance.

\section{LITERATURE REVIEW}

According to researchers, in the conditions of globalization processes, the focus on digital technologies is a priority for the innovative development of entrepreneurship [11], [12]. That is, the effective functioning of the subjects of market relations is possible when identifying alternative competitive development strategies, taking into account digital trends, where the key point is the rapid introduction of digital technologies in the economic activities of business entities [13], [12]. 
Under "digitization", E. B. Starodubtseva and O. M. Markova [14] understand the transformation of various information flows in the digital form. That is, the corresponding process allows to optimize economic activity using processing and transformation of large amounts of information.

However, according to S. J. Berman, the expansion of the network of use of digital technologies, can have negative economic and social consequences and cause the outflow of significant amounts of information to competitors. Given the turbulence of the market environment, the researcher notes that the digitization of entrepreneurship is the basis for the creation of new opportunities, values, and competencies, which in turn will form a sustainable competitive advantage [15].

According to researchers, digitization provides improvement of economic processes, management, interaction, public relations, production, satisfaction of information needs of citizens and business entities, as well as provision and receipt of services [16]-[18].

According to scientists, in the coming years, the global economy will be most affected by the spread of the mobile Internet, Internet of things, automation of routine intellectual work, cloud technologies, advanced robotics, 3D printing, etc. [19], [20].

Researchers have determined that the economy that uses digital technologies is called digital and the sphere that creates, implements, and serves them is called digital industry. The digital economy is a key engine of competitiveness, productivity, innovation, and overall economic growth in the global digital economy [21].

There is no doubt that the concept of the digital economy is inextricably linked with the concept of digital entrepreneurship. According to A.V. Streltsov et al., digital entrepreneurship is the ability to use digital media and technology to solve global challenges and create new opportunities; it is the use of digital technology for business, professional activities, etc. [22].

F. Susan believes that digital entrepreneurship is entrepreneurship using new digital technologies (especially social networks, large volumes of solutions for mobile devices, or "clouds"). The purpose of such use may be to improve business operations, invent new business models, improve the intellectual resources of the enterprise, or communicate with consumers and stakeholders [23].

For digitization to contribute to the development of entrepreneurial activity, first of all, according to K. Richter et al., it is necessary to identify relevant digital trends: increased volumes of digital conversion; use of smart technology and gadgets; increased personalization of data; optimization of production processes; provision of digital applications of smartphone owners; integration of SEO and content marketing; development of AR technology [24].

According to K. Kraus et al., the effective functioning of business in the conditions of digitization of the economy requires fundamental changes in the organization of entrepreneurial activity. Researchers believe that in modern business, only those enterprises that can generate innovation, identify strategic resources, and build competencies become successful. Innovation is seen as an important source of competitive advantage in the activities of globally operating enterprises and, in some industries, also an alternative condition for survival [25].

At the same time, according to researchers, the digital revolution has changed the environment of modern enterprises, creating primarily fundamentally new conditions for the activation of their innovative development. Undoubtedly, intellectual resources are largely due to the nature and specificity of existing business models, as well as the possibility of using relevant organizational forms of innovative entrepreneurial activity and adequate systems and methods of its investment support [26].

All of the above makes it necessary to consider education as a tool for managing information processes in the field of education, that is, we are talking about completely innovative educational programs of the so-called "digital education".

Under digital education, S. Salvati understands the use of electronic elements in the educational process to strengthen and change the educational experience. This means that technology will change the formats of learning and teaching. Information becomes a link between the student and the teacher in the process of education, including all information or messages transmitted in one or another material form. Education, thus, acts as an organizer (method) of information transfer and development of the student [27].

A. Yu. Uvarov [28] defines digital education as the science of the laws of transmission and perception of educational experience that occurs in physical and virtual realities based on the use of information and communications technologies. M. E. Weindorf-Sysoeva and M. L. Subocheva [29] point out that digital education is based on impact, interactivity, cooperation, and introduction of technological achievements (virtual reality, artificial intelligence, large databases, etc.) into education, while the main components of digital education are electronic didactics and design of pedagogical processes.

Research hypothesis: the development of business models of digital entrepreneurship is closely related to the dynamics of scientific and technological progress and requires the introduction of digital educational programs. 


\section{PROPOSED METHODOLOGY}

\subsection{General description}

The following theoretical and empirical methods were used in the study:

- theoretical: content analysis (analysis of the theoretical foundations of digital entrepreneurship); functional analysis (identification of the features of digitization of entrepreneurial activity); system analysis (systematization of the results of the study);

- empirical: an online survey of experts - representatives of the business community in the field of e-commerce (11 experts) and university professors in the field of economic orientation (15 experts) - a total of 26 people.

\subsection{Algorithm}

At the first stage of the study, the scientific literature on the problem of digital entrepreneurship and digital education was analyzed.

At the second stage of the study, we identified and summarized the key factors for effective development of business models and digital entrepreneurship, presented the components of the architecture of digital business, and developed methodological recommendations for the study objectives and content of the distance learning course corresponding to the thematic focus.

\subsection{Flow chart}

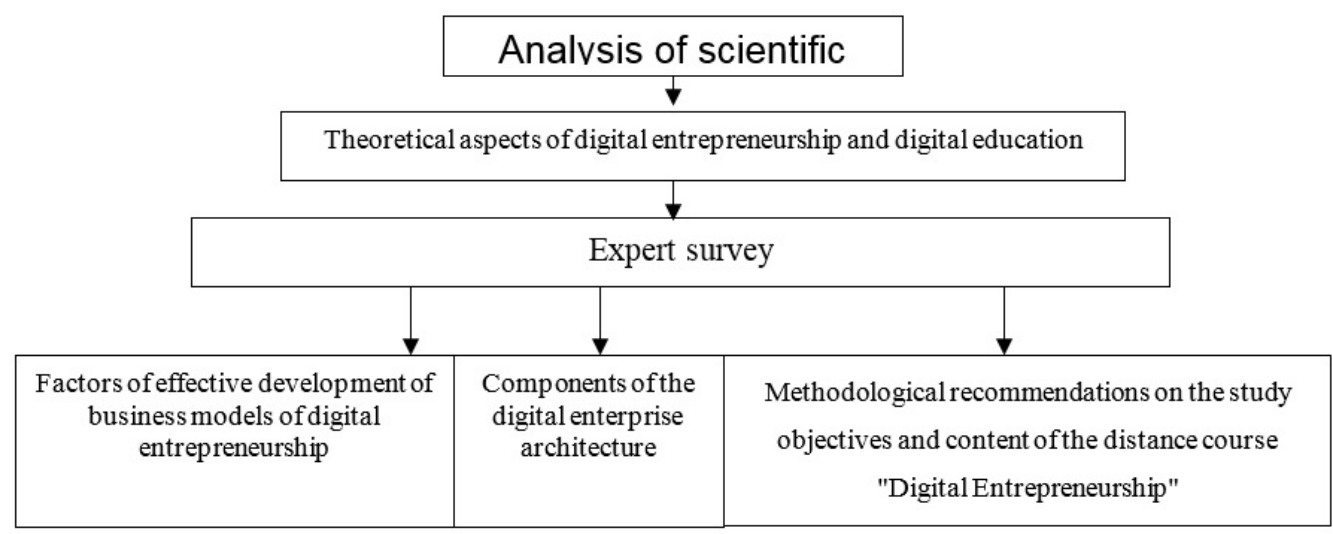

Figure 1: The research process

\section{RESULT ANALYSIS}

Based on the expert survey, the main factors of effective development of business models of digital entrepreneurship were identified (Table 1).

Table 1: Main factors of effective development of business models of digital entrepreneurship

\begin{tabular}{|l|l|l|}
\hline No & \multicolumn{1}{|c|}{ Factor } & \%* \\
\hline 1 & $\begin{array}{l}\text { The use of innovation in the formation of business models: only the constant search and implementation of new } \\
\text { business models or improvement of existing ones can lead to the success of digital entrepreneurship. }\end{array}$ & $88 \%$ \\
\hline 2 & $\begin{array}{l}\text { Adapting business models and strategies to volatile external environments: technologies and markets are } \\
\text { changing extremely rapidly. }\end{array}$ & $84.5 \%$ \\
\hline 3 & $\begin{array}{l}\text { Specialization on own features of business models and restrictions of links of a chain of values: possibility of } \\
\text { use of outsourcing in the activity of a firm that increases dynamism and organizational flexibility of the } \\
\text { company and promotes the most effective result in that sphere that manages it best of all. }\end{array}$ & $84.5 \%$ \\
\hline 4 & $\begin{array}{l}\text { Continuous technological development: a factor of maintaining technological leadership. } \\
\text { ensure profit growth. }\end{array}$ & $77 \%$ \\
\hline 6 & $\begin{array}{l}\text { Creating an electronic value chain that provides leadership by differentiating a product or service, by cost or by } \\
\text { optimal cost. }\end{array}$ & $73 \%$ \\
\hline
\end{tabular}

Note: compiled based on the expert survey; ${ }^{*}$ - percentage of expert mentions.

Taking into account the regulatory and legal aspects of the functioning of the sphere of digital entrepreneurship, as well as the existing list of concepts and categories, experts refer to the following sectors as components of the architecture of this sphere (Table 2). 
Table 2: Components of the digital enterprise architecture

\begin{tabular}{|l|l|l|}
\hline No & Digital enterprise architecture sector & $\mathbf{\%}$ \\
\hline 1 & normative-legal & $88 \%$ \\
\hline 2 & open data & $84.5 \%$ \\
\hline 3 & e-finance & $81 \%$ \\
\hline 4 & electronic accounting and reporting & $81 \%$ \\
\hline 5 & $\begin{array}{l}\text { digital technologies (identification, } \\
\text { authentication, blockchain, cloud computing, } \\
\text { and cognitive technologies) }\end{array}$ & $77 \%$ \\
\hline 6 & cryptographic protection of information & $77 \%$ \\
\hline 7 & internet advertising & $77 \%$ \\
\hline 8 & e-resources & $73 \%$ \\
\hline 9 & $\begin{array}{l}\text { electronic management (controlling, CRM, } \\
\text { electronic document management, e-project } \\
\text { management systems) }\end{array}$ & $73 \%$ \\
\hline 10 & e-staff training & $69 \%$ \\
\hline
\end{tabular}

Note: compiled based on the expert survey; * - percentage of expert mentions.
In these conditions, according to the experts, a decisive role in the process of training (retraining) and professional development of entrepreneurs is acquired by distance learning.

Taking into account the above, the experts proposed to organize a distance learning course "Digital Entrepreneurship" with the use of free software based on the basic platform of distance education Moodle, which integrates management databases, as well as specific services and training materials [30]. Installation of such a system by an IT-specialist on the server of an educational institution is practically cost-free.

The main objectives of the distance learning course "Digital Entrepreneurship", according to the experts, are presented in Table 3.

Table 3: Main objectives of the distance learning course "Digital Entrepreneurship"

\begin{tabular}{|c|c|c|}
\hline No & Task & $\% *$ \\
\hline 1 & $\begin{array}{l}\text { The study of the basic laws and mechanisms of the enterprise in the transition to the digital economy through } \\
\text { the use of electronic learning platforms. }\end{array}$ & $88 \%$ \\
\hline 2 & $\begin{array}{l}\text { Formation of theoretical knowledge and practical skills on the use of digital technologies, architecture, } \\
\text { infrastructure, and environmental resources in the process of the digital transformation of the economic sphere } \\
\text { using modern models of public-private partnership. }\end{array}$ & $84.5 \%$ \\
\hline 3 & $\begin{array}{l}\text { Consolidation of a complex of fundamental knowledge about general theoretical and practical bases of } \\
\text { processes of creation of market incentives, motivations, demand, and formation of requirements on the use of } \\
\text { digital technologies, as well as products and services among sectors of the economy, spheres of activity, } \\
\text { business, and society for their efficiency, competitiveness, and national development. }\end{array}$ & $81 \%$ \\
\hline 4 & $\begin{array}{l}\text { Electronic enterprise management, formation and use of production resources, including digital business } \\
\text { platforms. }\end{array}$ & $81 \%$ \\
\hline 5 & $\begin{array}{l}\text { The study of business processes in the management of enterprises in the period of the digital transformation of } \\
\text { the real sector of the economy, the main means (factors) of production of which are digital (electronic, virtual) } \\
\text { data, big data (big data), and CRM-systems. }\end{array}$ & $77 \%$ \\
\hline 6 & $\begin{array}{l}\text { Use and consumption of information, communications, and digital technologies for performance calculations } \\
\text { of the enterprise. }\end{array}$ & $73 \%$ \\
\hline 7 & $\begin{array}{l}\text { Consolidation of a complex of economic knowledge and assimilation of achievements of the theory and } \\
\text { practice of formation of the economy of the enterprise in the conditions of digitization of the market and } \\
\text { market relations. }\end{array}$ & $69 \%$ \\
\hline
\end{tabular}

Note: compiled based on the expert survey; * - percentage of expert mentions.

According to the experts, for the organization of teaching the distance course "Digital Entrepreneurship", it is possible to fill the course program with the following thematic content (Table 4).

Table 4: Thematic content of the distance course "Digital Entrepreneurship"

\begin{tabular}{|c|c|c|}
\hline No & Content module & Characteristics of the level \\
\hline 1 & $\begin{array}{l}\text { Digital entrepreneurship: prospects and } \\
\text { opportunities for development }\end{array}$ & $\begin{array}{l}\text { 1. Legal basis of digital entrepreneurship in Russia and the world. } \\
\text { 2. Digital technologies, architecture, and infrastructure of digital } \\
\text { entrepreneurship (smart city, smart region, smart country). } \\
\text { 3. Digital finance. Crypto industry and network payment systems. } \\
\text { 4. Systems of cryptographic protection of information and economic security. } \\
\text { 5. Identification and authentication of a person in cybernetic space. Electronic } \\
\text { digital signature. }\end{array}$ \\
\hline 2 & $\begin{array}{l}\text { Production resources of an enterprise of } \\
\text { modern digital entrepreneurship }\end{array}$ & $\begin{array}{l}\text { 6. Entrepreneurship as a subject of Industry } 4.0 \text {. } \\
\text { 7. Mechanisms of e-business. Electronic services and management systems. }\end{array}$ \\
\hline
\end{tabular}




\begin{tabular}{|c|c|c|}
\hline & & $\begin{array}{l}\text { 8. Main production resources of an enterprise in digital entrepreneurship. } \\
\text { Tangible and intangible environmental resources of an enterprise. Electronic } \\
\text { document circulation. } \\
\text { 9. Professional standard. Features of labour relations, HR, and self-employment. } \\
\text { 10. Electronic banking. Online financial calculations. }\end{array}$ \\
\hline 3 & $\begin{array}{l}\text { Results of operations and financing of } \\
\text { the development of digital } \\
\text { entrepreneurship }\end{array}$ & $\begin{array}{l}\text { 11. Revenues and expenses of the digital entrepreneurship enterprise. } \\
\text { Calculation of performance indicators. } \\
\text { 12. Virtual reality, robotics of production processes, big data, cloud and } \\
\text { cognitive technologies. } \\
\text { 13. Features of financing the development of the enterprise. Public-private } \\
\text { partnership. } \\
\text { 14. Internet advertising. Methods of promotion of products and services of an } \\
\text { enterprise on the Internet. }\end{array}$ \\
\hline
\end{tabular}

Note: compiled based on the expert survey.

The main types of training sessions, according to the experts, include interactive online lecture, video lecture (off-line), practical lesson, seminar in the form of a webinar, virtual laboratory work, consultation in the environment of "electronic mentor", and individual lesson (online or off-line).

Such approaches will make it possible to ensure the development of the educational component of digital entrepreneurship through the introduction of the proposed course "Digital Entrepreneurship" in the format of distance learning for training and retraining (advanced training) of entrepreneurs using the Moodle system.

\section{DISCUSSION}

According to the experts, the need to introduce the course "Digital Entrepreneurship" to the Russian education system is focused on the modern needs of social development, one of which is the formation of the so-called digital competence.

According to the definition of key competencies for lifelong learning (recommendation 2018/0008 (NLE) of the European Parliament and the Council of the EU), digital competence includes confident, critical, and responsible use and interaction with digital technologies for learning, work, and social participation. This includes information and data literacy, communication and collaboration, digital content creation (including programming), security (including digital well-being and cybersecurity-related competencies), and problem-solving [27].

The experts believe that in the training of future specialists in the field of entrepreneurship, it is necessary to introduce innovative didactic training tools that are based on the use of personal computers, cover a wide range of educational software.

At the same time, among the software for educational purposes, experts distinguish electronic training courses (ETC), software and pedagogical tools, electronic educational and methodological complex (EEMC), network programs and control and diagnostic systems.
ETC are dedicated to the study of a particular discipline. In addition to information materials, they should also contain materials for the organization of control and self-control tasks for self-fulfilment, questions for self-control, tests.

Software-pedagogical means are a set of computer programs for educational purposes. According to the experts, a modern software-pedagogical tool contains the following modules: electronic textbook, electronic reference book, training complex (computer models, designers, and simulators), task book, electronic laboratory workshop, computer testing system, and system for planning the learning process.

EEMC is a new type of learning tools, which includes the following components: abstract, course program and thematic plan, textbook for students (in the form of an interactive computer program, Internet resource), workbook, tasks for independent work, visual materials, glossary, references, and guidelines for teachers on the use of this complex. EEMC, as the experts emphasize, presents the content of the training course and offers a set of test and practical tasks, training exercises, laboratory, control and test works, recommendations, etc.

A variety of network programs are designed for students to work on tasks individually and for the teacher to control this process. To use such software for distance learning, it is necessary to connect students' computers to the teacher's workplace using remote monitoring software (for example, TeamViewer).

The main characteristic features of network programs include the following:

- ability to view on the monitor of the teacher's computer monitor content of any student's workplace, which allows one to control the process of completing the task by each student; - transfer of the content of the teacher's computer monitor to all students' workplaces and selectively to some of them allows advising students during their current tasks, watching this process on the teacher's computer monitor, interfere with the process of performing tasks by students, as well as 
switching the content of the student's workplace monitor screen to their screen;

- most of these software tools provide the ability to communicate over the network not only in visual mode but also support audio communication.

According to the experts, network programs are an indispensable assistant to the teacher in the organization of the practical part of the lesson. Individualization of training, differentiated approach to each student, personality-oriented method of teaching the subject, and interactivity of the implementation of the process of work of students during the performance of a fragment of practical training are very important as a methodological and psychological aspect of the use of network programs in the educational process. At the same time, the possibility of constant interaction between students and teachers in the network at a convenient time for them ensures the continuity of the educational process. Students create their content, using interactive videos and links to interesting web resources, and share it with others.

Also, according to the experts, an integral structural component of the educational process is the control and evaluation of knowledge, skills, and abilities of students. Based on the logic of the learning process, control is, on the one hand, the final component of mastering a certain content block and, on the other, a kind of link in the system of educational activity of the individual.

With the correct organization of the educational process, the control contributes to the development of memory, thinking, and speech of students, systematizes their knowledge, timely exposes the miscalculations of the educational process, and contributes to their prevention. Well-organized knowledge control contributes to the democratization of the educational process, its intensification, and differentiation of learning. It helps the teacher to get objective information about the course of educational and cognitive activity of students.

A variety of control and diagnostic systems are widely used to perform the control of students' knowledge. Modern control and diagnostic systems are based on computer technologies and can be used to control knowledge in any subjects, both in traditional and distance education. They can be useful both in terms of direct testing of knowledge, revision of the covered material, and self-testing. That is, they can be both official and non-official (in terms of their use). In any case, such systems help to improve the quality of knowledge and increase the intellectual level of students and teachers.

One of the promising areas of development of control and diagnostic systems, according to the experts, is the use of modern multimedia technologies in testing systems, as well as the widespread use of the Internet at various stages of testing. The use of multimedia technologies and Internet capabilities allows raising the quality and efficiency of knowledge testing systems to a new level. Therefore, according to one of the respondents, "the multimedia component of these systems will constantly grow and the use of multimedia will play a leading role in the development and effective application of knowledge testing systems, both in education and in business".

According to the experts, understanding the role and place of digital education in the educational process of the higher school allows one to approach the final selection of means and methods for educational activities of future specialists in the field of digital entrepreneurship.

\section{CONCLUSION}

The results of the study confirmed the hypothesis that the development of business models of digital entrepreneurship is closely related to the dynamics of scientific and technological progress and requires the introduction of digital educational programs. As for Russia, such factors as the development of information technology, innovation, and growth of potential audience and regular customers, as well as significant transformations at the macro-level, create new opportunities for the development of digital entrepreneurship as a component of the economy of the Russian Federation.

In neneral, digitization stimulates market actors to achieve a high level of innovation, competence, efficiencyб and responsibility фтв serves as a driver of success for the development of digital entrepreneurship with fundamentally positive results for companies and society. In turn, the relevant trends require the study of innovative business models and the search for new sources of attracting and generating intellectual resources.

The results of the study on the development of a comprehensive vision of the scope of digital entrepreneurship in Russia suggest distinguishing the following sectors: legal; open data; e-finance; electronic accounting and reporting; digital technologies; cryptographic protection of information; Internet advertising; electronic resources; e-management; e-learning and training. The foundation of the sphere of digital entrepreneurship is the concepts that fill the content of its main sectors, namely: "big data", "identification" and "authentication", "electronic services", "electronic management", "electronic banking", "cybersecurity", and "e-learning". Methodological recommendations and the described content of the course "Digital Entrepreneurship" will effectively introduce distance learning in educational institutions.

\section{REFERENCES}

1. Hristoforova, I., Silcheva, L., Arkhipova, T., Demenkova, A., \& Nikolskaya, E. Improvement of Digital Technologies in Marketing Communications of Tourism and Hospitality Enterprises. Journal of 
Environmental Management and Tourism, vol. 10(4), pp. 829-834, 2019.

2. Reznikova, O., Korolenko, J., Enenko, G., Tkachenko, D., \& Repnikova, V. Improvement of Approaches to Labor Regulation in Service Sector Enterprises. Journal of Environmental Management and Tourism, vol. 10(4), pp.886-891, 2019.

3. Regent, T., Glinkina, O., Ganina, S., Markova, O., \& Kozhina, V. Improvement of Strategic Management of a Tourism Enterprise in the International Market. Journal of Environmental Management and Tourism, vol. 10(2), pp.427-431, 2019.

4. G.I. Novolodskaya, T.Y. Kramarova, K.A. Lebedev, L.A.Ponkratova, E.Y. Chicherova. Public-Private Partnership as Innovative Form of Attraction of Financial Resources in Sphere of Tourism, Journal of Environmental Management and Tourism, [S.1.], vol. 9, no. 4, pp. 714-720, oct. 2018.

https://doi.org/10.14505//jemt.v9.4(28).04

5. Frolova, E., Polyakova, T., Dudin, M., Rusakova, E., \& Kucherenko, P. Information Security of Russia in the Digital Economy: The Economic and Legal Aspects. Journal of Advanced Research in Law and Economics, vol. 9(1), pp. 89-95, 2018.

https://doi.org/10.14505//jarle.v9.1(31).12

6. Mishakov, V., Beketova, O., Bykov, V., Krasnyaskaya, O., \& Vitushkina, M. Management Technologies to Adapt Modern Principles of Industrial Enterprise' Management. Journal of Advanced Research in Law and Economics, vol. 9(4), pp.1377-1381, 2018.

7. Bauer, M., Mussina, R., Bencheva, N., Ovchinnikova, T., \& Amerkhanova, I. Development Problems of Social Entrepreneurship in Kazakhstan. Journal of Advanced Research in Law and Economics, vol. 9(4), pp.1186-1195, 2018.

8. Sharafanova, E., Fedosenko, Y., \& Skhvediani, A. Regional Labor Market: Forecasting the Economic Effect of Cooperation between Universities and Entrepreneurs. Journal of Advanced Research in Law and Economics, vol. 8(6), pp.1908-1915, 2017.

9. Sitdikova, L. B.; Starodumova, S. J. Corporate agreement as a means of providing security in the course of entrepreneurship development, Entrepreneurship and Sustainability Issues, vol. 7(1), pp.324-335, 2019. https://doi.org/10.9770/jesi.2019.7.1(24)

10. M.N. Dudin, N.P. Ivashchenko, A.G. Gurinovich, O.M. Tolmachev, and L.A. Sonina. Environmental entrepreneurship: characteristics of organization and development, Entrepreneurship and Sustainability Issues, vol. 6, no. 4, pp. 1861-1871, 2019. https://doi.org/10.9770/jesi.2019.6.4(22)

11. E.G. Shumik, K.V. Smitskih. Assessment of the Dynamic Development of Entrepreneurship in the Cross-Border Areas International, Journal of Recent Technology and Engineering, vol. 8, no. 4, pp. 9579-86, November 2019.

https://doi.org/10.35940/ijrte.D9971.118419
12. D.A. Maximov, Y.V. Mishin, A.Y. Mishin, M.S. Shakhova, A.N. Zharov, and R.V. Lopukhina. Entrepreneurship in Educational Organisations: Innovations and Technologies, International Journal of Innovative Technology and Exploring Engineering, vol. 9, no. 1, pp. 3886-3891, November 2019. https://doi.org/10.35940/ijitee.A4980.119119

13. Smorodinskaja, N.V., Katukov, D.D. Kljuchevye cherty i posledstvija industrialnoj revoljucii [Key Features and Consequences of the Industrial Revolution], Innovacii, vol. 10 (228), pp.81-90, 2017.

14. Starodubceva, E.B., Markova, O.M. Cifrovaja transformacija mirovoj jekonomiki [Digital Transformation of the World Economy], Vestnik AGTU. Serija: Jekonomika, vol. 2, pp.7-15, 2018.

15. Berman, S.J. Digital Transformation: Opportunities to Create New Business Models, Strategy \& Leadership, vol. 40, no. 2, pp.16-24, 2012.

16. Burmeister, C., Lüttgens, D., Piller, F.T. Business Model Innovation for Industrie 4.0: Why the 'Industrial Internet' Mandates a New Perspective on Innovation, Die Unternehmung, vol. 70 no. 2, pp.124-152, 2016. https://doi.org/10.5771/0042-059X-2016-2-124

17. I.P. Gladilina, S.A. Kurbanov, D.A. Maximov, E.D. Dobrova, and K.B. Dobrova. Digital Franchising and Entrepreneurship: Effects of Digital Technology on the Relations of Business Process Participants, International Journal of Innovative Technology and Exploring Engineering, vol. 9, no. 1, pp. 3892-96, November 2019. https://doi.org/10.35940/ijitee.A4985.119119

18. V. Shapovalov, I. Igropulo, M. Arutyunyan. Practices of Defining the Notion of Social Entrepreneurship, International Journal of Innovative Technology and Exploring Engineering, vol. 9, no. 1, pp. 3790-94, November 2019.

19. Svahn, F., Mathiassen, L., Lindgren, R., Kane, G.C. Mastering the Digital Innovation Challenge, MIT Sloan Management Review, vol. 58, no. 3, pp.14-16, 2017.

20. E.V. Yaluner, O.A. Chesnova, S.A. Ivanov, D.G. Mikheeva, Y.A. Kalugina. Entrepreneurship Development: Technology, Structure, Innovations, International Journal of Recent Technology and Engineering, vol. 8, no. 2, pp.6020-25, July 2019. https://doi.org/10.35940/ijrte.B3732.078219

21. Lojko, V.I., Lucenko, E.V., Orlov, A.I. Sovremennaja cifrovaja jekonomika: monografija [Modern Digital Economy: Monograph], Krasnodar: KubGAU, 2018. p. 508.

22. Strelcov, A.V., Jakovlev, G.I., Nikulina, E.Ju. Obespechenie konkurentnyh preimushhestv promyshlennyh predprijatij $\mathrm{i}$ predprinimatelstvo $\mathrm{v}$ uslovijah cifrovoj jekonomiki [Ensuring Competitive Advantages of Industrial Enterprises and Entrepreneurship in the Digital Economy], Problemy razvitija predprijatij: teorija i praktika, vol. 1, pp. 253-261, 2018. 
23. Sussan, F., Acs, Z.J. The Digital Entrepreneurial Ecosystem, Small Business Economics, vol. 49 (1), pp. 55-73, 2017.

24. Richter, C., Kraus, S., Brem, A., Durst, S., Giselbrecht, C. Digital Entrepreneurship: Innovative Business Models for the Sharing Economy, Creativity and Innovation Management, vol. 26 (3), pp. 300-310, 2017. https://doi.org/10.1111/caim.12227

25. Kraus, S., Palmer, C., Kailer, N., Kallinger, F.L., Spitzer, J. Digital Entrepreneurship: a Research Agenda on New Business Models for the Twenty-first Century, International Journal of Entrepreneurial Behavior \& Research, vol. 25 (2), pp. 353- 375, 2019. https://doi.org/10.1108/IJEBR-06-2018-0425

26. Autio E., Nambisan S., Thomas L. D., Wright, M. Digital Affordances, Spatial Affordances, and the Genesis of Entrepreneurial Ecosystems// Strategic Entrepreneurship Journal, vol. 12(1), pp. 72-95, 2018.

27. Salavati, S. Use of Digital Technologies in Education: The Complexity of Teachers' Everyday Practice, Växjö, Sweden, 2016, p. 317.

28. Uvarov, A.Ju. Obrazovanie v mire cifrovyh tehnologij: na puti k cifrovoj transformacii [Education in the Digital World: Towards Digital Transformation], M.: Izd. dom GU-HSE, 2018, p. 168.

29. Weindorf-Sysoeva, M.E., Subocheva, M.L. "Cifrovoe obrazovanie" kak sistemoobrazujushhaja kategorija: podhody k opredeleniju ["Digital Education" as a System-forming Category: Approaches to the Definition], Vestnik MGOU. Serija: Pedagogika, vol. 3. pp. 25-36, 2018. https://doi.org/10.18384/2310-7219-2018-3-25-36

30. Hudjakova, A.V. Proektirovanie distancionnogo kursa na platforme Moodle 2.7 [The Design of the Distance Learning Course on the Moodle Platform 2.7.], Ucheb.-metod. posobie. Perm: PGGPU, 2014, p. 32. 